\title{
Comments on the Egyptian species of Ephedra L. (Ephedraceae)
}

\author{
Helmut Freitag \\ Institute of Biology, University of Kassel, Germany
}

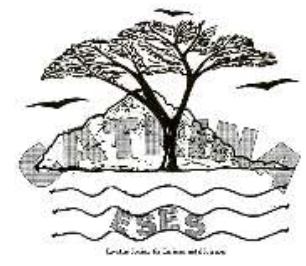

\begin{abstract}
The study deals critically with several aspects of the article "Taxonomic, DNA barcoding and phylogenetic reassessment of the Egyptian Ephedra L. (Ephedraceae)" by A. Faried et al. (2018). It provides additional information and corrections to the morphology and distribution of some species including an identification key based on vegetative characters, detailed distribution maps based on materials from all relevant herbaria and photos of the respective species taken in the field.
\end{abstract}

Keywords DNA barcoding, Ephedra distribution, Egyptian Ephedra, Phylogeny.

\section{INTRODUCTION}

Based on classical morphological characters, phylogenetic position and barcoding data as a tool for species identification of the genus Ephedra in Egypt, critical revisions were done by faried et al., (2018). Five taxa were documented: E. alata Decne., E. aphylla Forssk., E. foeminea Forssk., E. foliata Boiss. and E. pachyclada Boiss. subsp. sinaica (Riedl) Faried and Maier-Stolte. The morphological part of the published study is well done, with the pertinent differences in the shape and structure of leaf sheaths, female and male cones and seeds adequately illustrated by colour photos, except for $E$. foeminea.

Despite of serious efforts, the article suffers from several short-comings which impede its use. Here the more striking critical items are pinpointed and solutions are given for ambiguities:

\section{A. Available data concerning $E$. foeminea}

The authors argue that $E$. foeminea is not represented in the Egyptian herbaria which have been the only source for their study. However, there is material in herbaria of neighboring countries (NHJ in Jordan, BEI in Lebanon, HUJ in Israel, RIY in Saudi Arabia). Also, there are data available in the literature (e.g. Stapf 1889, Meikle 1977, under the synonyme E. fragilis var. subsp. campylopoda).

\section{B. Misleading distribution data \\ E. alata}

Additionally to correctly indicating the species' occurrence in all deserts of the country, they report it from the Mediterranean coastal strip as well, but no sample is cited among the voluminous list of representative specimens. As the reviewer is well acquainted with Egyptian Ephedra species from the field and from herbaria and has published pertinent distribution maps covering Egypt and adjoining countries (Freitag \& Maier-Stolte 1992), he seriously questions these findings. Upon inquiry, the authors referred to some online data, to the literature (Zahran \& Willis 2009) and to three specimens collected in the area. While the records from the first two sources appear to be questionable and do not allow any verification, the specimens were carefully checked by the reviewer: The specimen from Burg-el-Arab PRC404523 , tentatively identified as cf. E. alata by the collectors Osbornová-Kosinová \& Chrtek (06-04-1967) shows sessile microsporangia on a long protruding stalk-like sporangiophor which are typical traits of $E$. aphylla. The scans of the two others from sand dunes between Burg-e-Arab and Alamein (CAIM, ser. no. 0015384 named E. alata by the collector F. Saad (1603-1998) and $45 \mathrm{~km} \mathrm{~W}$ of Mersa Matruh (CAI, identified as E. alata by the collectors El-Garf \& Soliman (24-04-1996) do not allow to clearly recognize the reproductive organs but also most likely belong to E. aphylla, due to their delicate and bent branches. Based on the available findings, there is so far no evidence for the occurrence of E. alata on the Mediterranean coast, but of E. aphylla.

\section{Distribution map (1)}

Unfortunately the map is rather difficult to survey because it suggests being a dot map representing distinct records. Only later in the text the dots are explained as the species' occurrence in the phytogeographical regions as used by Boulos (1999). But these regions are not given in the map, and the map is inconsistent as four species are represented by one sign per region, while in case of $E$. foliata four signs appear scattered over the same region., Complete dot maps would give much more instructive information as may be seen in Map 1 where for convenience our maps from Freitag \& Maier-Stolte 1989, 1994) are reproduced. Because most of them were published in a treatment which is not in easy reach.

\section{Identification key}

The first alternative "Twigs flexible.." versus "Twigs rigid" is misleading, because the first statement only leads to E. foeminea, while also E. foliata is a climber with flexible twigs, and often E. aphylla as well. 

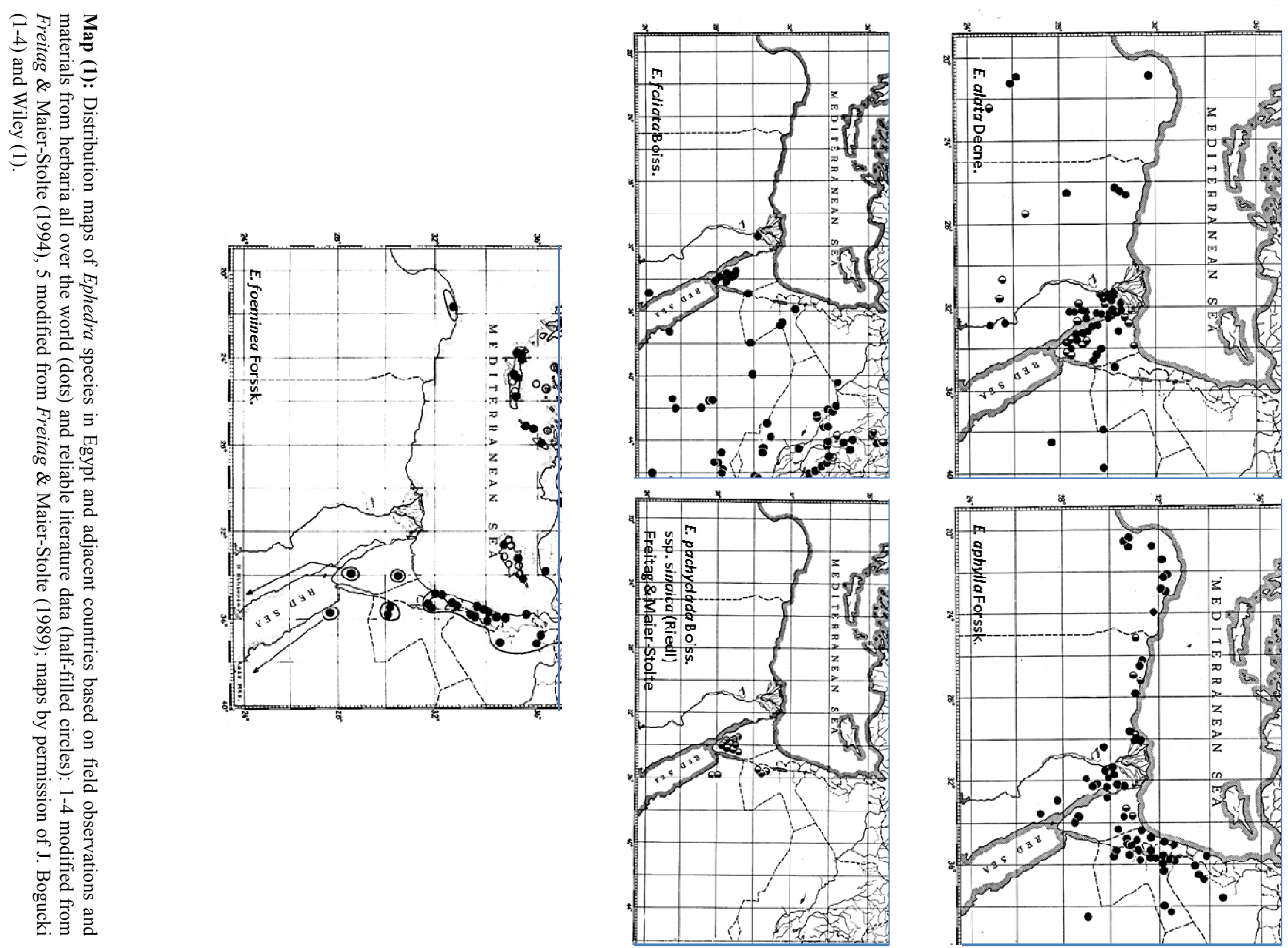
Furthermore, the size of seeds in E. foeminea is wrongly given as "up to $1 \mathrm{~mm}$ length". In fact, their length is 6-8 mm. As Ephedra species are notoriously difficult to identify because for most of the year they do not carry reproductive organs which are required in the traditional keys, it is regrettable that the authors did not present an additional key for identifying them by vegetative characters. The species differ so strikingly in habit, ecological requirements and distribution in Egypt that they can be keyed out easily by using these characters as shown below:

1. Plants erect, subshrubs or shrubs; branches rigid; pith brown, at least at periphery .2

- Plants creeping, climbing, pendant or overhanging, only young plants or individuals regenerate

from cuts erect; branches usually more delicate often bent; pith whitish throughout

3

2. Shrub up to $1,5 \mathrm{~m}$ in height; branches brownish green; in full deserts of low and medium altitudes

E. alata

- Subshrub up to $0.6 \mathrm{~m}$ in height; branches bluish; in semi deserts of high altitudes of the Sinai Mts.

\section{E. pachyclada}

3. Leaves with distinctly ciliate margins, sometimes well-developed (up to $2 \mathrm{~cm}$ long); older stems grey; preferably in dry Acacia shrublands of low and medium altitudes of the Sinai.....

E. foliata

- Leaves glabrous or minutely papillose, always very short; older stems grey or brown... .. 4

4. Older stems brown; very rare in dry shrublands of medium altitudes of the Sinai. ...

E. foeminea

- Older stems grey; in dry shrublands and semideserts of low and medium altitudes

E. aphylla.

The application of the paper for field botanists would also have profited by the addition of photographs showing the habit of typical individuals. Therefore, some images are given in Fig. 1.

\section{Molecular aspects}

In order to elucidate the phylogenetic position and to get DNA barcoding data ITS and trn-H/psb-A loci were sequenced and compared with data retrieved from GenBank. However, from the 5 Egyptian taxa altogether only 5 samples (without E. foeminea, and without citing the vouchers!) were taken and combined with data gained by Rydin et al. (2004). Furthermore, the cladogram in Fig. 1 clearly shows incongruencies in the placement of own and Genbank data for $E$. foliata and E. alata which are most likely caused by misidentifications on the one or the other side. As they are not discussed, they cast doubt on the respective interpretation. Probably the problem could have been solved by critical inspection of the vouchers.

\section{ACKNOWLEDGEMENTS}

The author gratefully acknowledges the readiness of A. Faried to discuss his article, the support of the colleagues from the National Museum of Prague (PR) who provided scans of herbarium material, the courtesy of the publishers J. Bogucki and Wiley for granting permissions to use the maps. He also thanks the anonymous reviewer who improved the manuscript linguistically.

\section{REFERENCES}

BOULOS, L. 1999. Flora of Egypt. Vol. 1. Al-Hadara Publishing, Cairo, pp. XII.

FREITAG, H. AND M. MAIER-STOLTE. 1989. The Ephedra-species of P. Forsskål: identity and typification. Taxon 38: 545-556. Doi: 10.2307/1222629.

FREITAG, H. AND M. MAIER-STOLTE 1994. Ephedraceae. In K. Browicz (ed.), Chorology of trees and shrubs in South-West Asia and adjacent regions. Vol. 10. Bogucki Wydawnictwo Naukowe, Poznan, pp. 5-16, 39-52.

MEIKLE, R.D. 1977. Flora of Cyprus. Vol.1. Bentham-Moxon Trust, Royal Botanic Gardens, Kew, pp. 33.

RYDIN, C, K.R. PEDERSEN AND E.M. FRIIS 2004. On the evolutionary history of Ephedra: Cretaceous fossils and extant molecules. Proceedings of the National Academy of Sciences 101(47): 1657116576. Doi 10.1073/pnas.0407588101.

STAPF, O. 1889. Die Arten der Gattung Ephedra. Denkschriften Kaiserl. Akad. Wiss. Wien 56, 2.Abt. Wien., pp. 53-59

ZAHRAN, M.A. AND A.J. WILLIS 2009. The vegetation of Egypt. Springer, Dordrecht. Doi: 10.1007/978-1-4020-8756-1. 


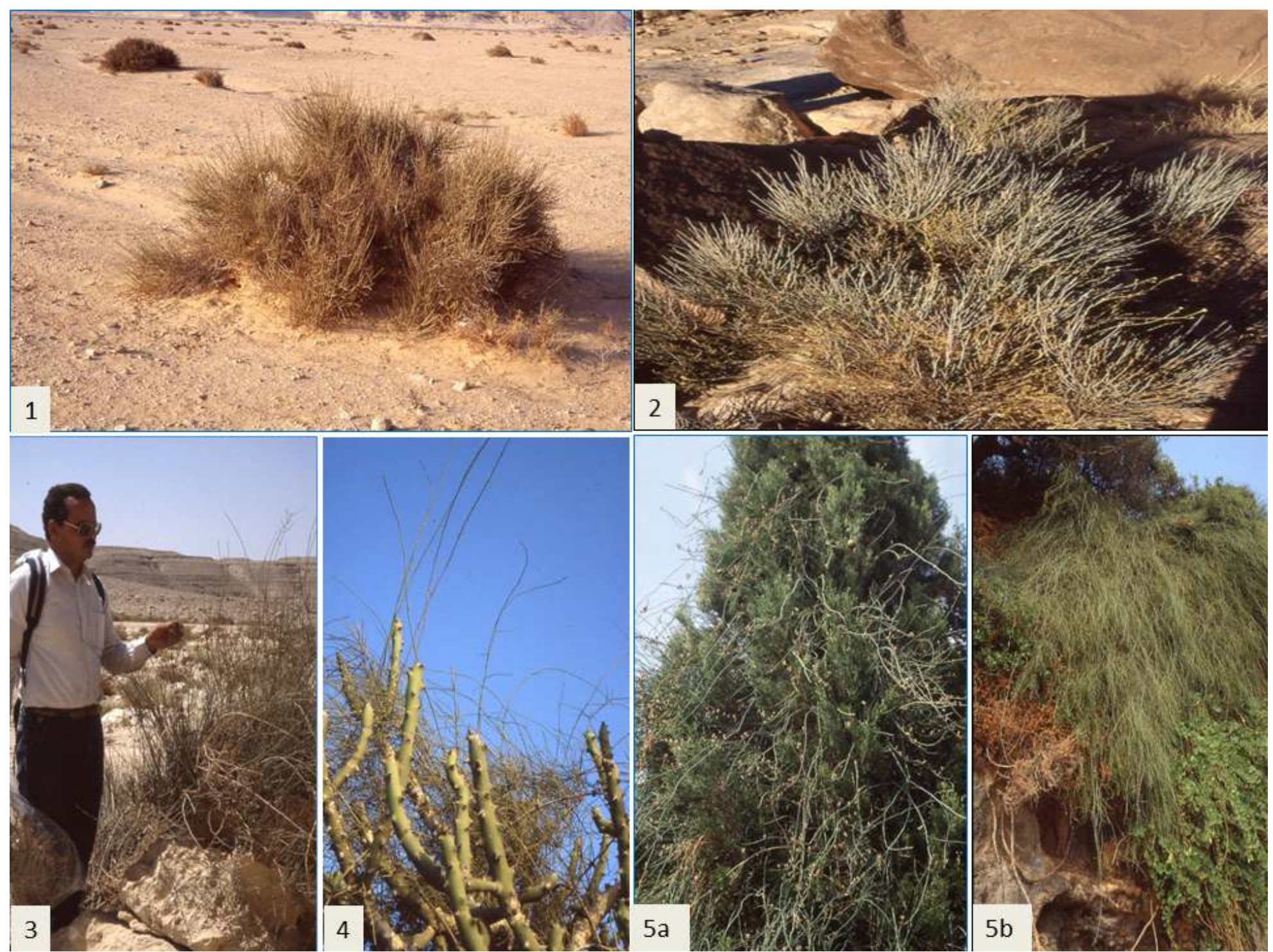

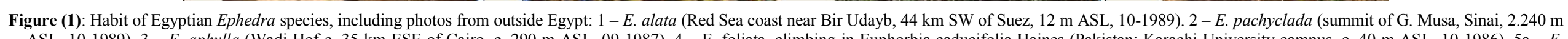

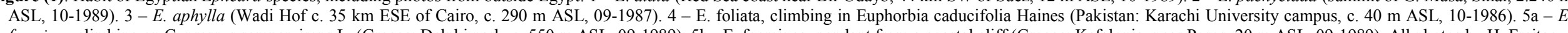

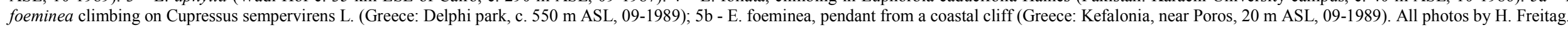

